MUZIKOLOŠKI ZBORNIK - MUSICOLOGICAL ANNUAL XII, LJUBLJANA 1976

UDK 92 Kogoj

\title{
IDENTITETA IN OTROŠTVO MARIJA KOGOJA
}

\author{
Pavle Merkù (Trst)
}

Že Ivan Grbec, pri katerem sem se v prvih povojnih letih učil harmonije in kontrapunkta, mi je govoril o vprašanju identitete Marija Kogoja. Pozneje mi je skladateljeva sestra Ana Kogoj Bratos, povedala, da se je Marij dobro spominjal - in je to zaupal svojcem in prijateljem - kako so $\mathrm{mu}$ v prvih otroških letih doma pravili Giulio in ne Mario (mati je bila Italijanka in doma so očitno govorili italijansko). Končno mi je to nedavno spet omenil Josip Vidmar, ki je v začetku dvajsetih let tesneje sodeloval s Kogojem. Ko me je ljubljanska Radiotelevizija lanskega avgusta povabila, naj sodelujem pri ciklusu oddaj, s katerimi je hotela počastiti osemdesetletnico skladatelja, sem se namenil osvetliti prav to vprašanje z raziskovanjem arhivskih dokumentov. Po večmesečnem brskanju po tržaških arhivih je zaživela pred mano bridka zgodba o štefanu Kogoju in njegovih otrocih: štirinajst let iz življenja slovenskega kmečkega fanta, ki ga je požrl Trst, ta "moloh slovenske krvi,» kakor ga je imenoval Alojz Rebula.

Skladateljev oče Štefan Kogoj se je rodil 14. oktobra $1864 \mathrm{v}$ Kanalu ob Soči: tako pravi rojstni list, ki ga je Štefan priložil ostalim dokumentom za poroko in ga hrani župnijski arhiv sv. Antona padovanskega (danes: sv. Antona Čudodelnika, ljudsko: sv. Antona novega, odslej žASA) (gl. seznam virov, dokument št. $1 / \mathrm{i}$ ). Njegov oče Janez je bil artifex, rokodelec, verjetno kolar: to je namreč poklic, ki ga je štefan prijavljal v prvih časih po prihodu v Trst.

$\mathrm{V}$ drugi polovici preteklega stoletja je Trst privabljal ogromne množice ljudi: prosta luka je privabljala predvsem trgovce $\mathrm{z}$ Bližnjega vzhoda in z južnega Balkana ter mornarje iz Dalmacije in Istre. Mesto se je naglo večalo in širilo, blagostanje je povzročilo mnogo investicij v privatnem in javnem sektorju. Za številna javna dela in zasebne pobude je bila potrebna delovna sila, ki so jo zagotavljali predvsem furlanski in slovenski težaki. Dvajsetletnega Štefana.Kogoja je očitno tudi zamikalo blagostanje, ki ga je obetalo bogato mesto. Kot specializiran rokodelec se je lahko nadejal celo boljše bodočnosti kakor lačni težaki, ki jim je bilo usojeno postati tržaški proletariat. Poročni list $\mathrm{v}$ ŽASA v samem mestnem središču nam pripoveduje, da je bil faber curruum, to je kolar, da je živel v Trstu že 4 leta, ko se je 5. avgusta 1888. poročil s petnajstletno Angelo Antonio Filippini, 
rojeno v Trstu, hčerjo brivca Santeja Filippinija in rajne Angele Cechet. (Viri, št. 1; gl. tudi sliko št. 2)

O Filippinijevih ne hrani tržaška občina nikakih podatkov, čeprav so bili Tržačani. Priimki pa kažejo, da so bili Angelini starši po poreklu Bezjaki iz krajev med furlanskim Tržičem (Monfalcone) in Krminom (Cormòns). Tudi oni so bili torej po vsej priliki lačna delovna sila, furlanska ali bezjaška, ki jo je tržaški moloh požrl. O njih nisem mogel izvedeti nič gotovega mimo dejstva, da je Angeli, skladateljevi materi, mati umrla, preden se je petnajstletna poročila; njen oče se je med tem časom spet poročil. (Viri, št. 1 in $1 /$ č) Mogoče je prav to dejstvo vplivalo na njeno usodo.

Prvi sin se je štefanu Kogoju in njegovi petnajstletni ženi Angeli rodil niti ne dva meseca po poroki: 3. oktobra istega 1888. leta. Ime mu je bilo Angelus Ioannes Stefanus, o njem vem le, da je živel v Trstu, da se ni nikoli imel za Slovenca, da je pel v nekem uglednem pevskem zboru in da je umrl brez otrok pred približno dvajsetimi leti. V njegovem krstnem listu (Viri, št.2) je oče štefan naveden kot carpentarius, tesar. Že ta podatek nam daje slutiti, da je začel poklicno propadati, saj je generično tesarsko delo gotovo manj cenjeno in manj rentabilno od specializacije, kar nedvomno predstavlja poklic kolarja. Tudi krstni listi naslednjih otrok izpričujejo isti generični poklic tesarja, pokažejo nam pa tudi socialni ambient, $v$ katerem so Kogojevi živeli: hči Anna Justina Francisca, rojena 1. 1890 (Viri, št. 3), naslednji sin Julius Dante Aloysius, rojen 1. 1892 (Viri, št. 4; slika št. 3), sin Marius Franciscus Ioannes, rojen 27. aprila 1895 (ne maja, kakor navajajo nekatere zgodovine ter enciklopedije, - Viri, št. 6; slika št. 4) in hči Anna Valentina Maria, rojena 1. 1897 (Viri, št. 8) nosijo po tri imena: pri prvem sinu sta dve imeni dejansko imeni staršev, pri naslednjih štirih otrocih sta dve imeni vedno enaki imenom krstnih botrov. Ko bi bil socialni ambient, v katerem so Kogojevi živeli, za spoznanje boljši, bi smeli morebiti sklepati o kaki modi. Ker so bili očitno - kakor se bomo z lahkoto prepričali lačni, lahko razberemo $\mathrm{v}$ samih imenih prošnjo za skromno življenjsko pomoč sicer gotovo revnim krstnim botrom. Berimo imena in poklic krstnih botrov Kogojevih otrok: Antonius Kogoj krojač; Margartha (sic!) Kogoj samska; Franciscus Sovranus in Augustinus Sovranus kovača; Aloysius Viezzi kmet; Julius Sullich nosač ali grobar (bajulus lahko pomeni oboje); Ioannes Stanic kočijaž; Franciscus Vattovaz vrtnar; Valentinus Zaratini tudi kočijaž; Anna Mayer je označena le kot nubilis, samska. (Viri, št. 2, 3, 4, 6, 8; sliki št. 3 in 4.) Iz teh krstnih listov razberemo le še naslov družine: ko se je rodil Angelo, so stanovali na ulici Istituto; ko se je rodila prva Ana, so stanovali na ulici San Maurizio; pozneje vedno na Barriera Vecchia, št. 28 v Marijevem krstnem listu je očitna pomota. (gl. sliko št. 1).

Drugi otrok, hči Anna Justina Francisca, je kmalu umrla. Knjiga mrtvih v ŻASA nam spet pojasnjuje marsikaj novega. Stara tri leta in pol je hči umrla doma zaradi bronhitisa. Oče je naveden kot kočijaž. Pogrebni razred: četrti. (Viri, št. 5) V nekaj letih naletimo torej že na tretji očetov poklic, kar tolmačimo kot znamenje, da je bil njegov dejanski poklic zelo nestalen in zaslužek zelo boren. Vendar je moral biti zaslužek $\mathrm{v}$ tem času vsaj tolikšen, da so otroku privoščili najnižjo kategorijo plačanega pogreba. Ko je dve leti pozneje umrl sin Marij, mu niso mogli starši prirediti 
niti tako skromnega pogreba: pokopan je bil brezplačno s pogrebom revežev. $V$ Marijevem smrtnem listu je oče naveden $\mathrm{z}$ drugačnim poklicem: ephippiarius, to je sedlar. (Viri, št. 7; slika št. 5)

Tudi četrti otrok Kogojevih je umrl. Marij Kogoj je umrl 31. januarja 1896, 8 mesecev star, zaradi meningitisa. Toliko v župnijskem arhivu. Tržaška občina hrani še tehtnejši dokument: izjavo občinskega zdravnika, ki je pregledoval trupelce, ugotovil vzrok smrti in izdal dovoljenje za pogreb. Podpis tega zdravnika je nečitljiv in nas tudi ne zanima. Na uradnem papirju piše dobesedno, da je leta 1896, meseca januarja, dne 31 . ob petih popoldne umrl Marij, sin Štefana Kogoja in Angele Filippini, rojen v Trstu 1. 1895. Oče je po poklicu sedlar. Stanujejo na ulici Barriera Vecchia št. 18 $\mathrm{v}$ podstrešju in otrok je tu umrl zaradi meningitisa. Pokopan ima biti v 48 urah. Za otroke, ki umrejo $\mathrm{v}$ prvem letu življenja, je treba navesti tudi način dojitve in zato izvemo, da ga je dojila mati. Izvemo tudi za ime zdravnika, ki ga je - vsaj uradno - zdravil: pisal se je Dr. A. Merli. Pod nečitljivim podpisom občinskega zdravnika, ki je sestavil ta dokument, mora biti podpis osebe, ki je povedala vse osebne podatke rajnega; podpis z okorno pisavo je jasen: Maria Filippini, očitno materina sorodnica, menda njena mačeha. (prim. Viri, št. 1/č; opisan dokument v Virih pri št. 10; slika št. 6)

O Mariju Kogoju vemo torej danes vse, kar se vedeti da: a nas ne zanima več. Zakaj ni bil slovenski skladatelj, ki je s tem imenom znan.

Skladatelj je očitno bil Julius Dante Aloysius Kogoj, rojen 30. septembra $1892 \mathrm{v}$ podstrešju na Barrieri Vecchii št. 18. Ugotovitev daje prav Grbčevi izjavi, da je bil skladatelj Marij Kogoj videti starejši, kakor so v resnici pričali njegovi dokumenti, saj danes vemo, da je imel dokumente po tri leta mlajšem bratu Mariju.

Za Julijem ni ne v ŽASA ne $v$ župnijskem arhivu tržaške glavne bolnišnice smrtnih podatkov. Da sem se o tem prepričal, sem preverjal $\mathrm{v}$ obeh uradih po 15 let knjig mrtvih. Pa tudi na anagrafskem uradu tržaške občine (odslej ATO) so na družinskem listu Štefana Kogoja prvotno vpisali Marijev smrtni datum, dosti let pozneje so ga prečrtali in vpisali pripombo: l. 1917 gojenec Glasbene Akademije na Dunaju in so k Juliju vpisali Vse kaže, da je umrl 31.1.1896. S temi pripombami je legenda že prekrila resnico. (Viri, št. 11; sliki št. 7 in 8) Po mojih letošnjih ugotovitvah (1975) v ŽASA in ATO ob neovrgljivi priči smrtne ugotovitve občinskega zdravnika (Viri, št. 10) so, kakor je razvidno po sliki št. 7, v anagrafskem uradu tržaške občine ta dokument (št. 11) uradno popravili.

Da lažje razumemo usodo in glasbo skladatelja Marija Kogoja, moramo torej skušati rekonstruirati življenjsko pot drugega otroka štefana Kogoja, sina Julija Danteja Alojzija. Prvi podatek po krstu, na katerega naletimo, je vznemirljiv: Kanalsko županstvo v Goriškem okraju javlja tržaški občini, da je potrdilo o pristojnosti Kogojevih $\mathrm{h}$ kanalski občini poslalo 8. marca 1895 mestni bolnišnici c.k. okrajnega kapitanata v Gorici v zadevi sina Julija. Iz tega dopisa, ki ni ohranjen, ampak je izpričan po vpisu na dokumentu št. 11 (gl. sliko št. 8), smemo sklepati, da je bil triletni Julij nekaj časa $\mathrm{v}$ goriški bolnišnici. Zakaj? To bo nemogoče dokumentirati: arhiv goriške mestne bolnišnice je bil z bolniki vred. med prvo svetovno vojsko, 
ko je bila Gorica sredi operacijskega ozemlja, poslan v Trst; vsa povpraševanja in pregledi po tržaških arhivih so pa bila doslej negativna: nihče mi ni vedel pojasniti usodo tega arhiva. Vendar lahko sklepamo, da je moral biti vzrok za to Julijevo prisotnost v goriški bolnišnici resen, saj vemo, da so sicer otroci v družini Štefana Kogoja umirali v istem podstrešju, v katerem so se bili rodili, tudi s hudimi boleznimi. Zato smemo domnevati za bolezen ali travmo $\mathrm{v}$ tretjem letu starosti, ki bi lahko vsaj delno pojasnila poznejšo skladateljevo umsko bolezen.

Ko je naslednje leto umrl Marij, je bil Julij vsekakor doma: star je štiri leta in mu nenadoma umre osem mescev star bratec; odslej so ga doma klicali z imenom mrtvega. Dovolj je bil star, da si vse to zapomni. To je psihična travma, ki ga je spremljala vse življenje, saj je to grozljivo storijo pripovedoval vsem bližjim.

Naslednji usodni udarec ga je doletel dve leti pozneje. Leta 1898, meseca januarja, dne 8., ob pol štirih zjutraj je v glavni tržaški bolnišnici umrl Štefan Kogoj rajnega Janeza in rajne Lucije iz goriškega Kanala. Star je bil 33 let. Bolezen ali vzrok smrti: jetika. Toliko v knjigi mrtvih tržaške bolnišnice. (Viri, št. 9) Vemo, da je doma pustil tri otroke: osemletnega Angela, šestletnega Julija-Marija in enoletno Ano. Dva otroka sta umrla pred njim: prva Ana in Marij. Zapustil je tudi petindvajsetletno vdovo. Podatki se skladajo z onimi, ki jih hrani ATO. Lahko dodamo nekaj ugotovitev, ki se nam vsiljujejo po branju vseh teh dokumentov. Dvajsetletni specializirani rokodelec, ki je prišel iskat sreče in boljšega življenja v mesto trgovine in obilja, je počasi propadal, verjetno ni imel stalnega poklica in zaslužka in se je občasno lotil vsakega dela, s katerim je skušal družino ščititi pred iakoto in razsulom: bil je kolar in tesar, kočijaž in sedlar. A verjetno tudi brezposeln. Kakšne socialne in zdravstvene posledice je imelo to propadanje, lahko le slutimo. Njegova zgodnja smrt nam jih potrjuje.

$\mathrm{V}$ tržaških arhivih nisem mogel doslej dokumentirati $\mathrm{z}$ uradnim akti usode vdove in otrok. $\mathrm{V}$ dokumentih ATO je Angela Filippini prisotna do leta 1898, to je do leta moževe smrti. Potem ne vemo o nji nič več do leta 1919. Hči Ana mi je pred leti pripovedovala, da je mati imela zelo lep sopranski glas in da je izginila iz Trsta $z$ neko operetno družino. Tega se ni mogla Ana spominjati drugače kakor iz pripovedovanja ljudi, saj je bila stara eno leto, ko je oče umrl in mati izginila. Taki glasovi od povsod in od nikoder pripovedujejo, da je mati šla v Egipt ali v Brazilijo. V ATO se pojavlja le še enkrat: dne 4. aprila 1919 je dokumentirana njena prisotnost v Trstu, njeno bivališče je Via dei Cavazzeni, št. 6 (Viri, št. 11; sliki št. 1 in 8): to je tesna, smrdljiva uličica $v$ starem mestu. Potem ne vemo o nji prav nič več.

Enako nisem mogel dokumentirati, kdo je poslal dva otroka: Julija, kł so ga že vsi imeli za Marija, in Ano v Kanal kot vaški siroti, ki jih je imela občina rediti.

Marij Kogoj, krščen za Julija, je tedaj bil šest let star. Dovolj, da je nosil v sebi številne kali in vzroke za svojo usodo. Lahko slutimo nekaj genetičnih lastnosti, podedovanih po očetu in po materi. Vemo pa za tri travme, ki niso mogle biti brez posledic: bolezen $\mathrm{v}$ starosti treh let, pre- 
imenovanje $\mathrm{z}$ imenom mrtvega bratca eno leto pozneje, $\mathrm{v}$ sestem letu starosti očetova smrt, materin beg in izgon iz rojstnega Trsta, da ga je redila doslej neznana slovenska vas. $\mathrm{S}$ tem $\mathrm{v}$ zvezi lahko vsaj hipotiziramo novo travmo: prehod iz italijanskega mestnega proletarskega ambienta v slovenski vaški kmečki ambient. Da ni bilo tako, bi ne imeli slovenskega skladatelja Marija Kogoja.

\title{
VIRI
}

Seznam dokumentov $\mathrm{v}$ župnijskem arhivu sv. Antona Padovanskega v Trstu:

1. XIV Liber Copulatorum civitatis Theresianae, 1888-1892, str. 10, št. 282: poročni list Štefana Kogoja in Angele Filippini, gl. sliko št. 2. S številko $353 \mathrm{v}$ zadnjem stolpcu tega dokumenta je označen fascikel, v katerem hranijo dokumente, ki sta jih Štefan Kogoj in Angela Filippini vložila, in sicer:

a) Razsodek o odmeri vojaške takse za leto 1887. Slovenska tiskovina, izpolnjena s črnilom. Izhaja, da so bili štefanovi starši revni.

b) Confessio Paschalis ..., potrdilo, da sta bili novoporočenca pri velikonocni spovedi.

c) Latinska tiskovina, izpričevalo, da sta opravila nauk za poročence.

č) Italijansko rokopisno potrdilo o bivališču za A. Filippini na papirju z intestacijo Dr. Gioacchino Coen / Avvocato / Trieste. Datum: 21. 6. 1888. Izvirni tekst:

Certifico che Angelina Filippini figlia di Santo Filippini e della defunta Angelina abita al quinto piano della mia Realità No 727/34 in Via dell'Acquedotto in uno al suddetto di lei padre ed alla matrigna Marietta Filippini nata Mattusti.

Gioacchino Coen

Iz tega izvemo le, da se je Sante Filippini vdrugič poročil in da so stanovali $\checkmark$ petem, menda zadnjem nadstropju.

d) Italijansko rokopisno potrdilo o bivališču S. Kogoja. Datum: 12. 7. 1888. Izvirnik:

Certificato che Stefano Kogoj figlio di Giovanni Kogoj e della Lucia nata Stanich abita al secondo Piano $\mathrm{N} 12$ Via Chiozza della mia Realità in uno al suddetto di lui padre ed alla madre Kogoj nata Stanich.

Sebastiano Viola

Štefan je torej stanoval $\mathrm{v}$ drugem nadstropju na ulici Chiozza 12 skupaj s starši. So bili ti v Trstu zaradi sinove poroke ali so stanovali delj časa v Trstu? Hišni lastnik Sebastiano Viola je bil priča pri Štefanovi poroki in je v njegovem porocnem listu naveden kot kovač (faber ferraius). Morebiti je bil štefanov delodajalec, saj je Štefan $\mathrm{v}$ prvih dokumentih naveden kot faber curruum, to je kolar.

e) Italijansko rokopisno privoljenje Santeja Filippinija, da se sme mladoletna hči omožiti.

f) Rojstni list Angele Filippini. Edini novi podatek $v$ njem je, da se je rodila na ulici Amalia, št. 20.

g) Dovoljenje

Jaz Janez Kogoj, oče Ștefana iz Kanala h. št. 41 dovoljujem, da se imenovani moj sin Stefan sme oženiti.

Kanal, dne 15. junija 1888

\author{
Janez Kogoj \\ p. m. Fr. Vidic (Vidiz?) prica \\ Andrej Drašcek \\ prica
}

Od začetka do Vidicevega podpisa in naslednje besede "priču je pisava ista, očitno Vidičeva. Draščk pa se je podpisal sam. Kaže torej, da je bil Janez Kogoj slabo pismen ali nepismen. Vidic je bil kanalski župnik.

h) Testimonium status liberi, latinska tiskovina izpolnjena ročno, datirana Kanal, die 15. Junii 1888, podpisana Fr. Vidiz Par.

1) Rojstni list Štefana Kogoja. Izvirnik: 
Fides Nativitatis et Baptismi

Anno Domini millesimo octingentesimo sexagesimo quarto mense Octobris die decimaquarta i.e. 14. Octobris 1864 natus est et die eadem in hac Ecclesia parochiali B. M. V. Assumptae ritu catholico baptizatus fuit Infantis Nomen et Cognomen: Staphanus Kogoj

Locus natalis et $\mathrm{N}$. us D. us: Canale 41

Pater: Joannes Kogoj artfiex filius Antonii et Mariannae

Mater: Lucia nata Stanič e Canale filia Michaelis et Catharinae

Patrini: Stefano Kralj bandajo et Maria Stanič

Sacerdos qui baptizavit: Staphanus Breščak I. Coop.

Archivio conservato ... (omissis) ...

24. 8. 1886

Valentinus Bresaunig I. Coop.

2. XXII Liber Baptizatorum in ecclesia S. Antonii Patavini Tergesti, 188-91, str. 185: rojstni list prvega otroka, po imenu Angelus Ioannes Stefanus, rojen 3. oktobra 1888, stanujoč Via Istituto 12. Oče je naveden kot carpentarius, to je tesar. Botra sta Antonius Kogoj sarte (?) in Margaretha Kogoj nubil(is).

3. ibidem, str. 602: rojstni list drugega otroka, po imenu Anna Justina Francisca, rojena 3. septembra 1890, stanujoča na ul. Maurizio 2. Oče je spet naveden kot carpentarius. Botra sta Franciscus Sovrano faber ferr. in Augustinus Macorini faber ferr.

4. 23. Liber Baptizatorum in ecclesia S. Antonii Patavini Tergesti, 1891-93, str. 340; št. 1241: rojstni list tretjega otroka, po imenu Julius Dante Aloysius, gl. sliko št. 3.

5. XIV Liber Defunctorum Parochiae S.ti Antonii Patavini Tergesti, 1892-97, str. 229: smrtni list drugega otroka Anna filia Stephani Cogoj auriga de Goritia, stanujoča na Barriera 18. Umrla je 16. marca 1894, stara 3 leta in 6 mescev, od bronhitisa. Exequiar 18. Classe funerum: 4.

6. 24. Liber Baptizatorum in ecclesia S. Antonii Patavini Tergesti, 1894-95, str. 286, št. 721: rojstni list četrtega otroka, po imenu Marius Franciscus Ioannes, gl. sliko št. 4.

7. XIV Liber Defunctorum Parochiae S. ti Antonii Patavini Tergesti, 1892-97, str. 419, št. 88: smrtni list četrtega otroka Marius, gl. sliko št. 5.

8. 25. Liber Baptizatorum in ecclesia S. Antonii Patavini Tergesti, str. 21: rojstni list petega otroka, po imenu Anna Valentina Maria, rojena 12. januarja 1897, stanujoča na Via Barriera Vecchia 18, oče je naveden kot carpentarius. Botra sta Valentinus Zaratini rhedarius in Anna Mayer nubilis.

Ana Kogoj por. Bratos je umrla v Trstu 3. marca 1969.

Dokument v župnijskem arhivu tržaške glavne bolnišnice:

9. XXI Liber Defunctorum str. 5: smrtni list Štefana Kogoja. Cogoi Stephanus e Canale je umrl 8. januarja 1898 ob pol štirih zjutraj. Numerus progressivus 41. Poklic: caruccar. Starost: 33. Vzrok smrti: tuberc.

Dokumenta $\mathrm{v}$ arhivu anagrafskega urada tržaške občine:

10. Civico Ufficio statistico anagrafico: Biglietto di constatazione di morte, gl. sliko št. 6 .

11. Kartotečni list s podatki za družino Kogoj.

\section{POJASNILA K TEKSTU IN VIROM}

1. Izsek iz topografske karte mesta Trst iz 1. 1883, priložene $\mathrm{k}$ vodiču ॥Illustrierter Führer durch Triest und Umgebungen", Hartleben's Verlag, Wien, 1883.

Via Amalia, 20 (danes Via Giuseppe Gatteri, 24), rojstna hiša Angele Filippini, Kogojeve matere.

Via Aquedotto, 34 (danes Viale $X X$ Settembre, 32): tu je Angela Filippini stanovala zadnje leto pred poroko.

Via Chiozza, 12 (danes Via Francesco Crispi, 12): tu je stanoval stefan Kogoj, skladateljev oče, zadnja štiri leta pred poroko. 
Cerkev sv. Antona padovanskega (danes sv. Antona Cudodelnika, ljudsko sv. Antona novega): tu so se 5. 8. 1888 poročili Kogojevi starši, tu so bili krščeni vsi njuni otroci.

Via Istituto, 12 (danes Via Giovanni Pascoli, 14): tu so Kogojevi stanovali, ko se je 3. 10. 1888 rodil prvi otrok Angelus Joannes Stephanus.

Via San Maurizio, 2: tu so Kogojevi stanovali, ko se je 3. 9. 1890 rodil drugi otrok Anna Justina Francisca.

Via Barriera Vecchia, 18 (hiša je bila $\mathrm{v}$ tridesetih letih porušena, stala je v zahodnem delu današnjega Largo Barriera Vecchia, približno tam, kjer je danes avtobusna postaja): to so nadalje stanovali Kogojevi do štefanove smrti; v podstrešju so se tu rodili trije otroci, dva pa sta umrla:

20. 9. 1892 se je rodil Julius Dante Aloysius (skladatelj Marij Kogoj);

16. 3. 1894 je umrla Anna Justina Francisca;

27. 4. 1895 se je rodil, 31. 1. 1896 je umrl Marius Franciscus Joannes;

12. 1.1897 se je rodila Anna Valentina Maria.

Mestna bolnišnica: tu je 8. 1. 1898 umrl od tuberkuloze štefan Kogoj.

Via dei Cavazzeni, 6: tu je stanovala Angela Filippini, vd. Kogoj, 4. 4. 1919.

Bivališče Via Rigutti 21, kjer so Kogojevi stanovali 1. 1891, leži pri Sv. Jakobu.

2. Poročni list Kogojevih staršev v XIV Liber Copulatorum civitatis Theresianae, 1888-1892, str. 10, št. 282, v župnijskem arhivu sv. Antona Padovanskega v Trstu v terezianski četrti. Beremo, da se je 5. avgusta 1888 Stephanus Kogoj faber curruum (iz) Canalis, stanujoč na Via Chiozza 12 že 4 leta, katoliške veroizpovedi, rojen 14. 10. 1864 in zato 23 let star, očeta Ioannes Kogoj artifex in matere Lucia r. Stanič, poročil z Angelo Antonio Filippini privata, rojeno v Trstu, stanujočo že 1 leto v Via Acquedottis 34, katoličanko, rojeno 7. 5. 1873 in zato 15 let staro, hčerjo Sanctus Filippini barbitonsor et defuncta Angela r. Cechet. Priči sta bili Sebastianus Viola faber ferr. in Josephus Kogoj inserviens. Zvezal ju je kaplan Clemens Scubla.

3. Rojstni list Julija Kogoja v 23. Liber Baptizatorum in ecclesia S. Antonii Patavini Tergesti, 1891-1893, str. 340, št. 1241. Beremo, da je 16. oktobra 1892 kaplan Josephus Alič (?) krstil otroka z imeni Iulius Dante Aloysius, rojen 20. septembra tega leta. Otrok je katoličan, moškega spola, zakonski sin. Oče je Stephanus Kogoj carpentarius de Canale, mati je Angela r. Filippini. Priči sta Aloysius Viezzi agricultor in Iulius Sullich bajulus. Babica je bila Lucia Bertoli.

4. Rojstni list Marija Kogoja $\mathrm{V}$ Liber Baptizatorum in ecclesia S. Antonii Patavini Tergesti, $1894-1895$, str. 286, št. 721. Naslov Kogojevih je tu naveden $28 \mathrm{Via}$ Barriera in je očitna pomota, zakaj $\mathrm{v}$ vseh drugih dokumentih je navedena hišna številka 18. Beremo, da je 3. junija 1895 kaplan Ioannes Ianossevich (?) krstil otroka z imeni Marius Franciscus Ioannes. Rojstni dan je 27. april 1895. Starši so navedeni kakor $\mathrm{v}$ prejšnjem dokumentu, priči sta Ioannes Stanich auriga in Fran. ciscus vattovaz hortolanus.

5. Smrtni list Marija Kogoja v XIV Liber Defunctorum Parochiae S.ti Antonii Patavani Tergesti, 1892-1897, str. 419, št. 88. Beremo: prvotno napisano ime Maria je popravljeno v Marius, priimek je vpisan v obliki Cogoi (kolebanje med slovenskim in italijanskim pravopisom $\mathrm{v}$ teh župnijskih knjigah je pravilo, nikakor izjema!), zakonski sin Stephani, ephippiarii in Angeline r. Filippini, rojen v Trstu, pert(inens) Canali, to je pristojen v Kanal; spol je bil sprva označen kot ženski, nato popravljen v moški. Starost na dan smrti: 0 let, 8 mescev, 0 dni. Vzrok smrti: meningitis. Umrl 31. 1. 1896. Pokopan naj bo 2. 2. 1896. Pogrebne obrede je opravil kaplan Iulius Warto. Razred pogreba: $g$. Kaj ta "gu pomeni, nisem mogel ugotoviti niti pri predstavnikih starejšega klera. Menda pomeni generalis. Sicer stojijo v ti rubriki, poleg črke $g$, številke od 1 do 4 . Domnevam, da odgovarjajo številke štirim plačanim razredom, z $g$ pa naj bi označevali neplačani pogreb, najskromnejšo obliko pogreba pač.

6. List o ugotovitvi smrti, ki ga hrani anagrafski urad tržaške občine. Leta 1896, meseca januarja, dne 31. ob 5. popoldne je Mario Cogoi moškega spola, sin Stefana in Angeline $r$. Filippini, star 8 mescev, rojen v Trstu, pristojen h goriškemu Kanalu, očetov poklic: konjski sedlar, katoliške veroizpovedi, stanujoč na ulici Barriera Vecchia št. $18 \mathrm{v}$ podstrešju, umrl zaradi meningitisa. Po besedah Luogo 
della seguita morte, to je kraj smrti, berem dom, kar je kratica za domicilio, to je stanovanje: pomeni, da je Marij Kogoj umrl v podstrešju, kjer so Kogojevi stanovali. C̆as, ki je predpisan za pogreb: 48 ur. Za otroke, ki so umrli v prvem letu starosti, je treba navesti, ali je bilo dojenje materino, dojiljino, umetno ali mešano; zapisano je mat, to je kratica za materno, to je materino. Ime zdravnika, ki je rajnega zdravil: $D(r)$. A. Merli. V Trstu, 1. 2. 96. Sledi nečitljiv podpis občinskega zdravnika. Spodaj je še podpis osebe, ki je obiskujočemu (inšpektorju) posredovala podatke o rajnem: Maria Filippini. Verjetno je to mačeha Kogojeve matere, gl. Vire, št. $1 / \check{c}$.

7. Družinski kartotečni list štefana Kogoja, ki ga hrani anagrafski urad tržaške občine. Do leta 1924 so uradno vodili pregled prebivalstva le župnijski uradi, od tega leta dalje tržaška občina. Prejšnji dokumenti tržaške občine niso bili ne uradni ne popolni. Zato si je razlagati, da manjkajo $\mathrm{v}$ tem arhivu podatki o družini Filippini. Na glavni strani tega kartotečnega lista je najprej zapisano ime Kogoi Stefano. Zapisovanje slovenskih priimkov je bilo $\mathrm{v}$ tem času zelo aleatorično, pač po posluhu in po znanju ljudi, ki so te primke zapisovali.

$\mathrm{V}$ prvi vrsti beremo ime družinskega poglavarja, oznako moškega spola, ime staršev, rojstni kraj in letnico, oznako katoliške veroizpovedi, datum poroke, datum smrti in oznako poklica: tesar. Ker manjkajo datumi posameznih zapisov in je pisava pri vseh sedmih članih družine ista in enotna, se da sklepati, da je bil ta list sestavljen po štefanovi smrti.

Stevilka 2 je Angela, skladateljeva mati, podatki grejo do stolpca o veroizpovedi. Manjka oznaka, kje in kdaj je umrla.

Stevilka 3 je prvi sin Angelo Giov(an)ni. S poznejšo pisavo so vpisani podatki o poroki in smrti.

Številka 4 je drugi otrok Anna.

Śtevilka 5 je skladatelj Giulio Dante s podatki do stolpca z rojstnim datumom. Križec po imenu in vprašaj $\mathrm{v}$ stolpcu s smrtnim datumom sta bila očitno vpisana istočasno $z$ opombo na koncu sedme vrste.

Tu se dejanski vrstni red otrok po rojstnih letnicah neha: številka 6 je peti otrok Anna. Po smrtnem datumu sledi še opomba, da je treba nadaljnje podatke o nji iskati $\mathrm{v}$ kartotečnem listu moža.

Številka 7 v sedmi vrsti je četrti otrok Mario. Sprva je roka, ki je sestavila ta družinski list, vpisala križec pred otrokovim imenom, kar je spet dokaz, da je bil list sestavljen po štefanovi smrti, in smrtni datum. Leta 1917 je druga roka precrtala križec pred imenom, radirala smrtni datum in vpisala opombo: allievo musicista accademia di Vienna, to je gojenec glasbene akademije na Dunaju. Tedaj je ista roka dodala križec za imenom Giulio Dante in vpisala vprašaj v stolpec za smrtni datum.

Zvezdico na koncu sedme vrste in opombo $v$ vrstah 10.-13. je vpisal letos občinski funkcionar Luigi Venanzi, ki mi je $\mathrm{z}$ veliko vljudnostjo in prizadevnostjo pomagal raziskovati arhivske dokumente o Kogojevih: na podlagi lastnih in mojih ugotovitev je v opombi citiral potrdilo o smrti Marija Kogoja (gl. sliko št. 6) in zapisal, da veljajo opombe $\mathrm{k}$ št. 7 na hrbtni strani tega lista za št. 5 in narobe.

8. Hrbtna stran istega dokumenta (Viri, št. 11). Na levi strani zgoraj (Pertinen$z a$, to je pristojnost) je opomba, po kateri izvemo, da je bil Julij Kogoj leta 1895 $\mathrm{v}$ goriški bolnici. Sledi opomba, da je za št. 2 in 6 , to je za mater Angelo in hॅer Ano, kraljeva Prefektura $v$ Gorici brisala Stefana in Ano iz seznama pristojnih prebivalcev Kanala ob Soči: letnica je 1932.

Na desni strani zgoraj (Annotazioni, to je beležke) nas zanimata prvi dve beležki. Prva zadeva številko 7, to je Marija: Vive ed abita a Vienna - Grüngasse 11 a/4, živi in stanuje na Dunaju, Grüngasse 11 a/4. Citiran je dopis z leta 1917. Naslednja zadeva številko 5, to je Julija: Dovrebbe esser decesso li 31. 1. 1896., naj bi bil umrl 31. 1. 1896. Naslednje beležke zadevajo ostala dva otroka, ki sta do smrti živela $\mathrm{v}$ Trstu.

$\mathrm{V}$ spodnjem delu lista so beležke, ki zadevajo stanovanja Kogojeve družine. Via Chiozza 12 (1887) je, kakor vemo, Stefanovo bivališče od prihoda v Trst do poroke. Via Istituto 12 (1888) je prvo bivališče zakoncev Stefana in Angele Kogoj, tu se je rodil prvi otrok. Via S. Maurizio 2 (1889/90) je drugo bivališce zakoncev, 
tu se je rodil drugi otrok. Tu so stanovali tudi ob popisu prebivalstva leta 1890 . Naslednje, doslej še neizpričano bivališče Kogojevih, je Via Rigutti 21 (1891), končno še Barriera Vecchia 18 (1892/1898): vse naslednje opombe razen ene zadevajo stevilki 3 in 6, to je dva otroka, Angela in Ano, ki sta živela v Trstu. Ena sama opomba zadeva številko 2, mater: 4. 4. 19. je stanovala na Via (dei) Cavazzeni 6.

\section{SUMMARY}

On the basis of available material the author tries to establish the precise identity of the Slovene composer Marij Kogoj. Following this aim, he makes use of the documentation to be found in the parish archives of St. Anthony the Miracle-Worker in Triest.

The composer's father Stephan Kogoj and his wife Angela had five children, two of whom Anna Justina and Marij, died early, the latter at the age of eight months, in 1896. The author comes to the conclusion that the composer Marij Kogoj is actually Julius Dante Aloysius Kogoj. This is supported by the fact that there are no death data regarding Julius in the cited archives. In the family register Marij's death date entered, but was later crossed out, with the remark: 1917, student of the Musical Academy in Vienna - whereas Julius received an additional remark showing that he must have died on Jan. 31, 1896. On the basis of surviving documentation the author assumes that Julius was in hospital at the age of three, for which there must have been a sufficient reason. There is the hypothesis of a possible trauma (which might account for the composer's later malady). Also, it has been reputed that the composer, generally known under the name of Mario, on occasions said that after the death of his brother Mario he came to be called after the name of his deceased brother. 


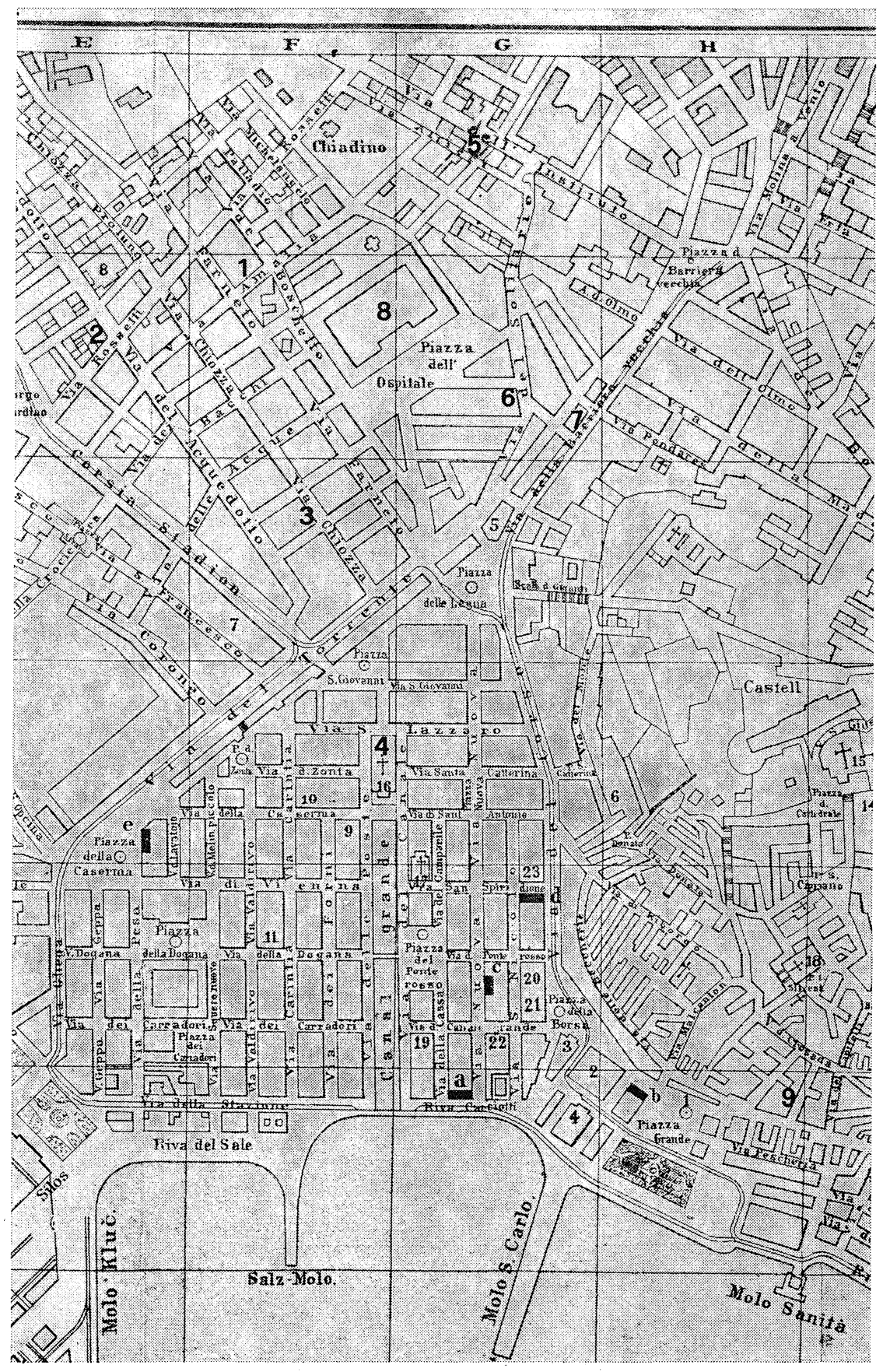

Slika št. 1 


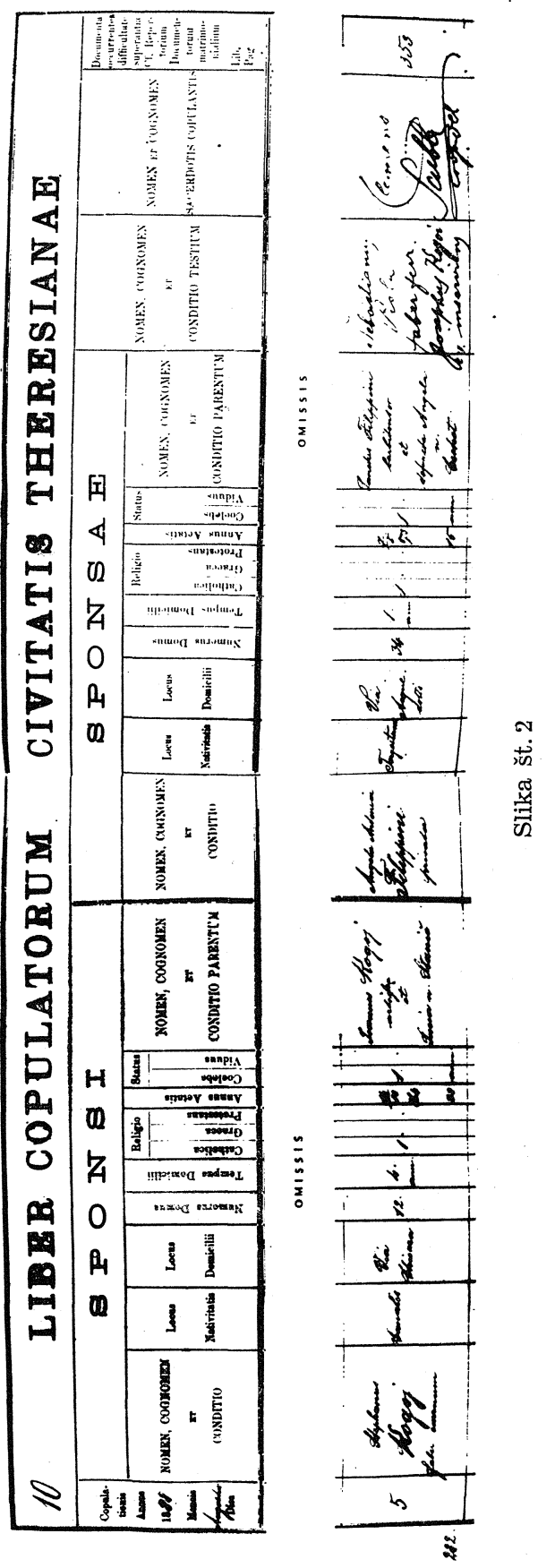




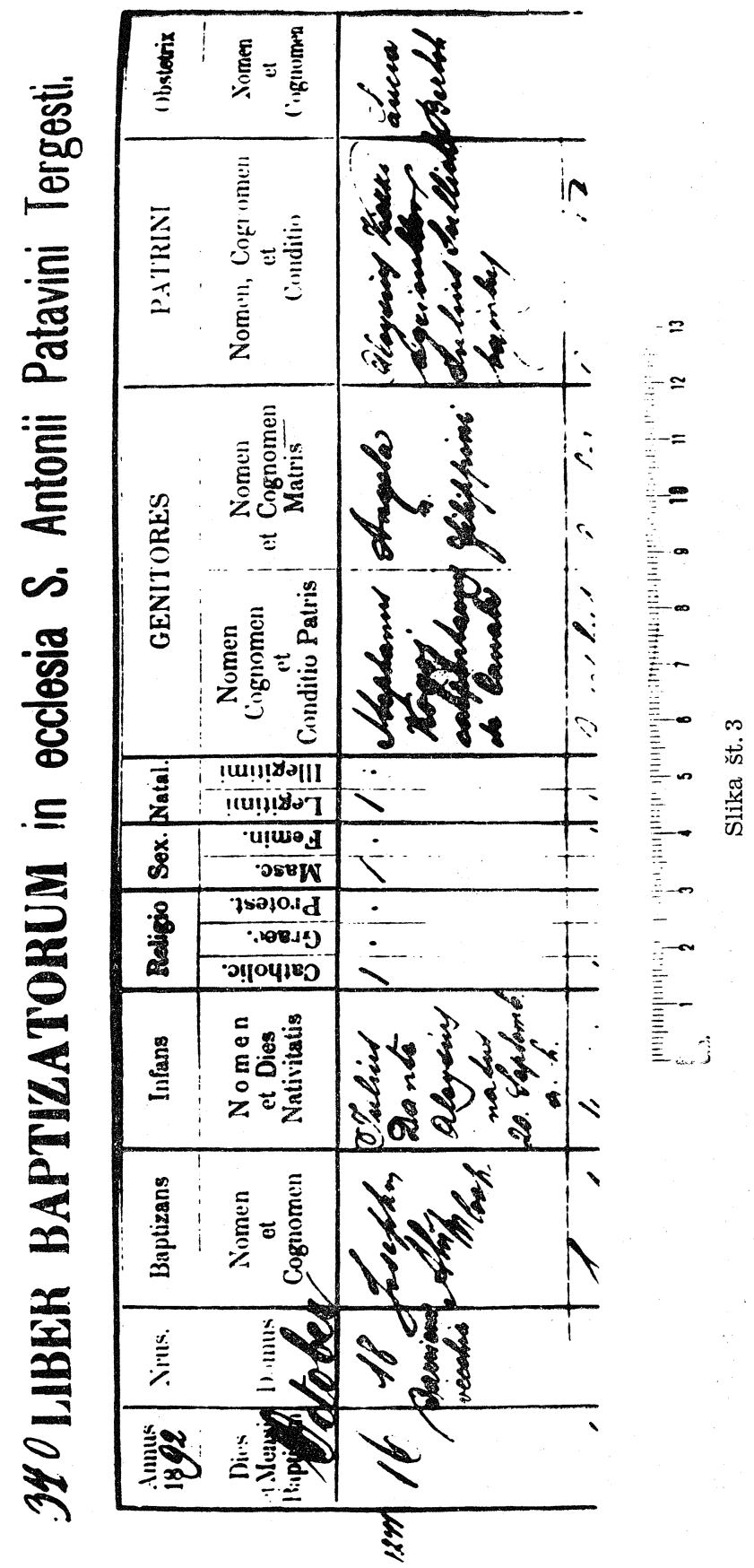



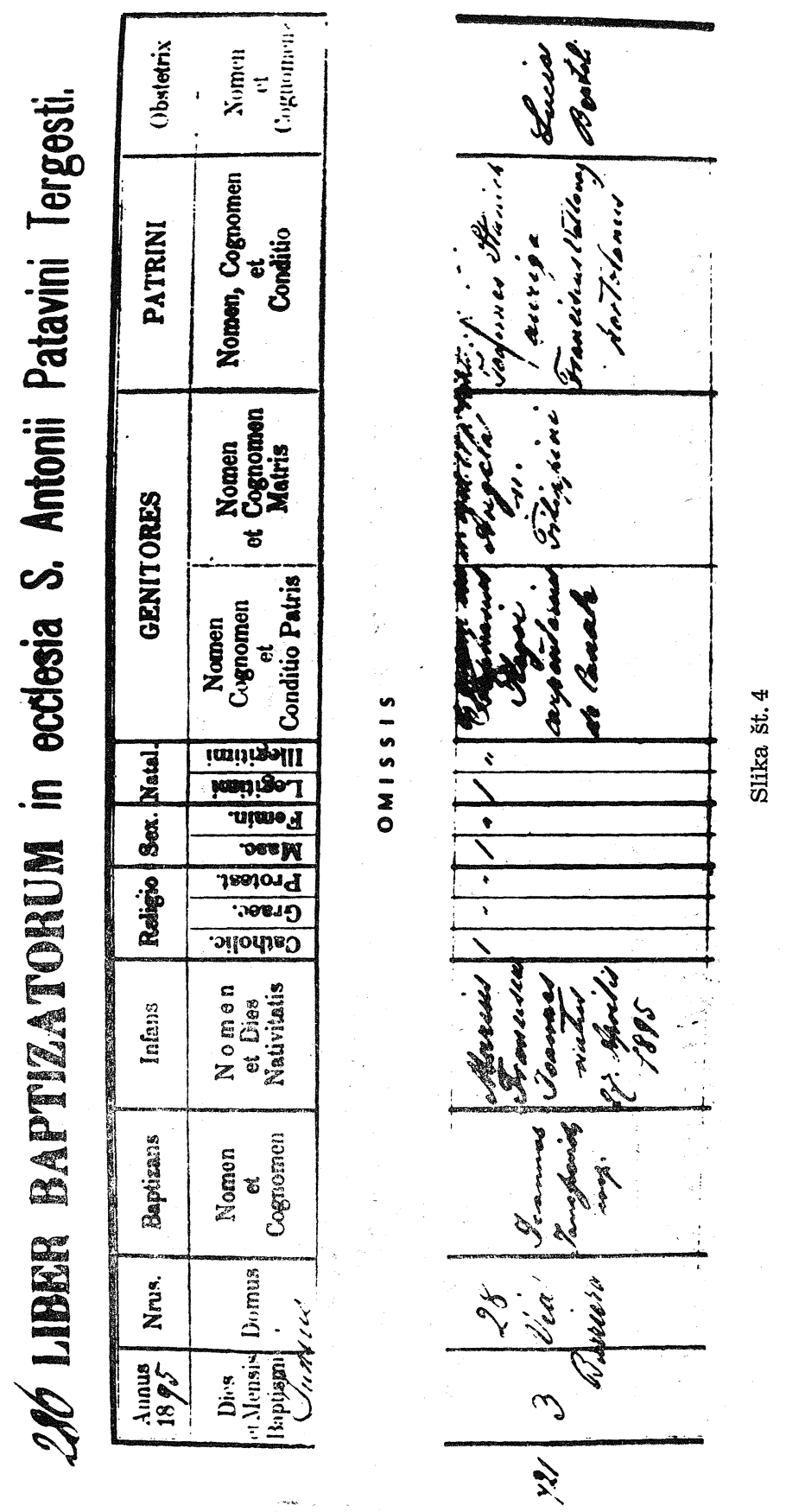


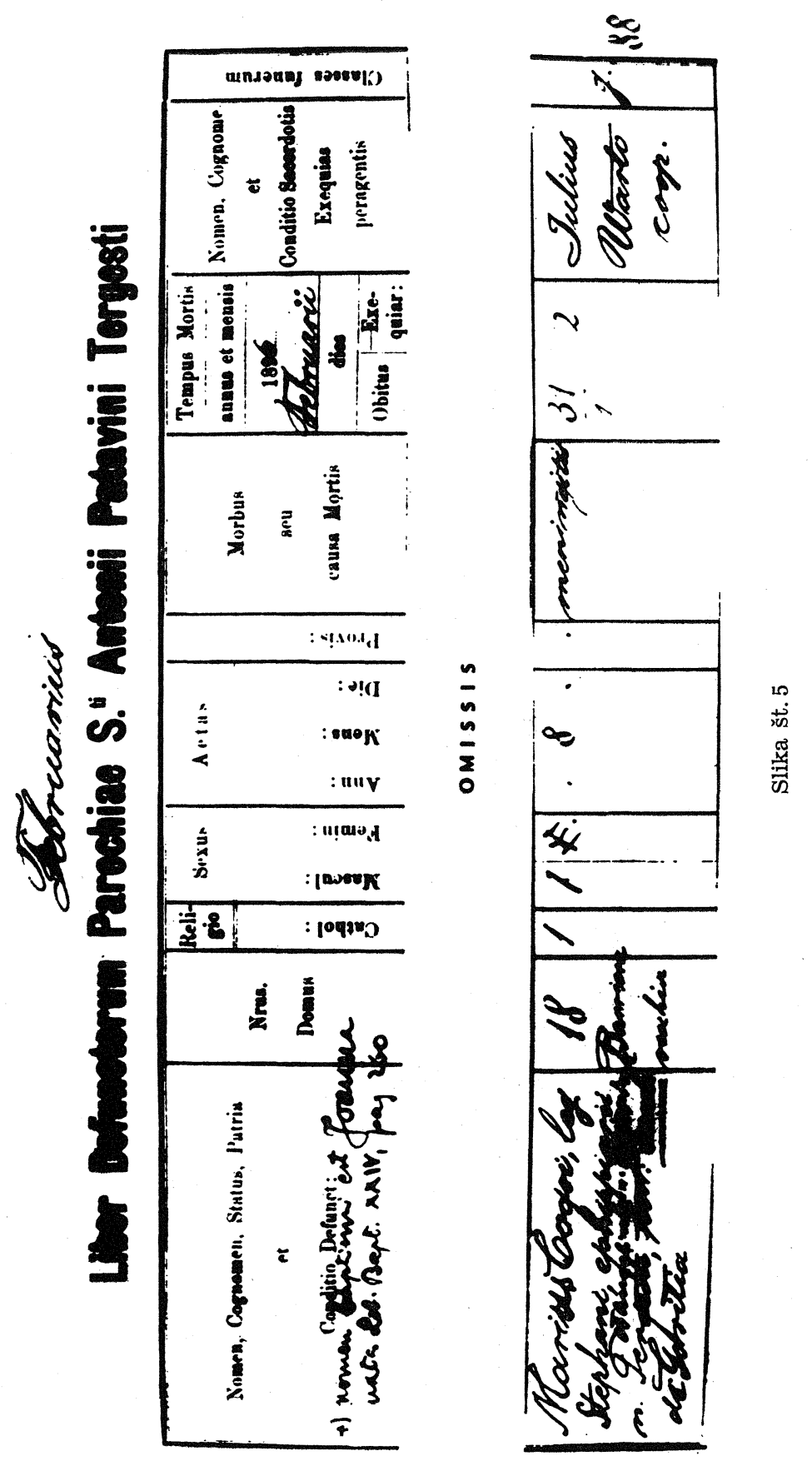




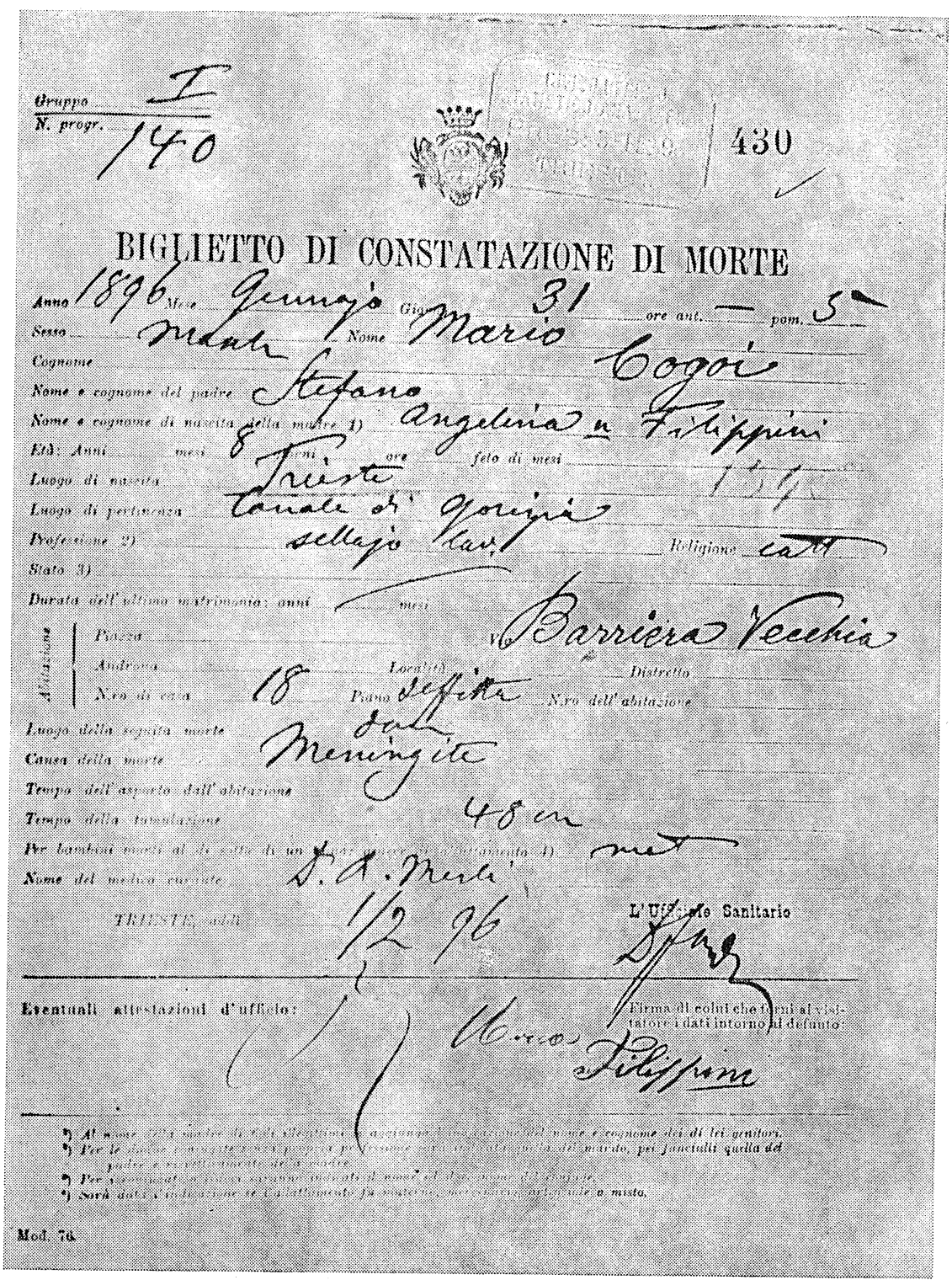

Slika št. 6 


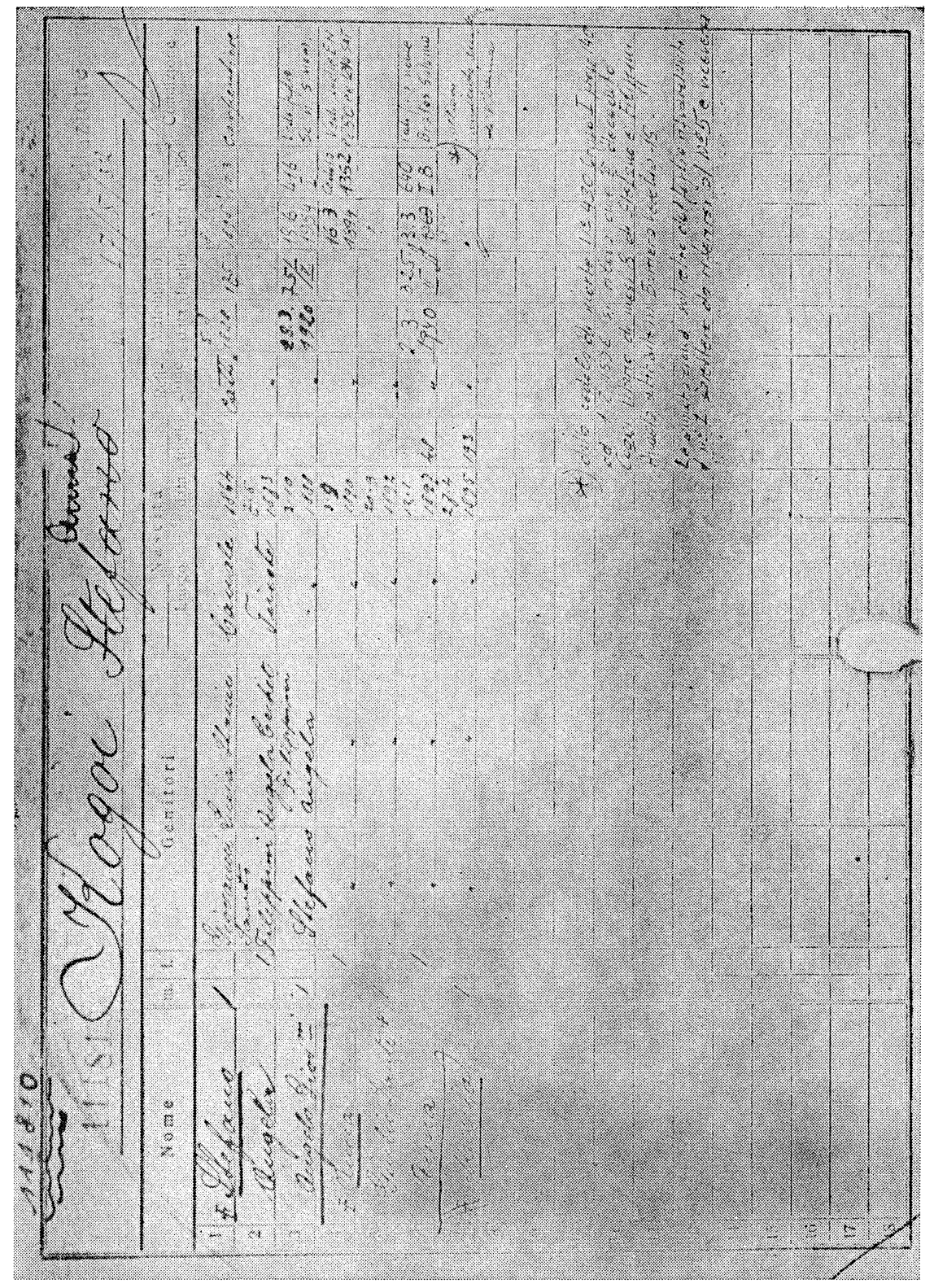

Slika št. 7 


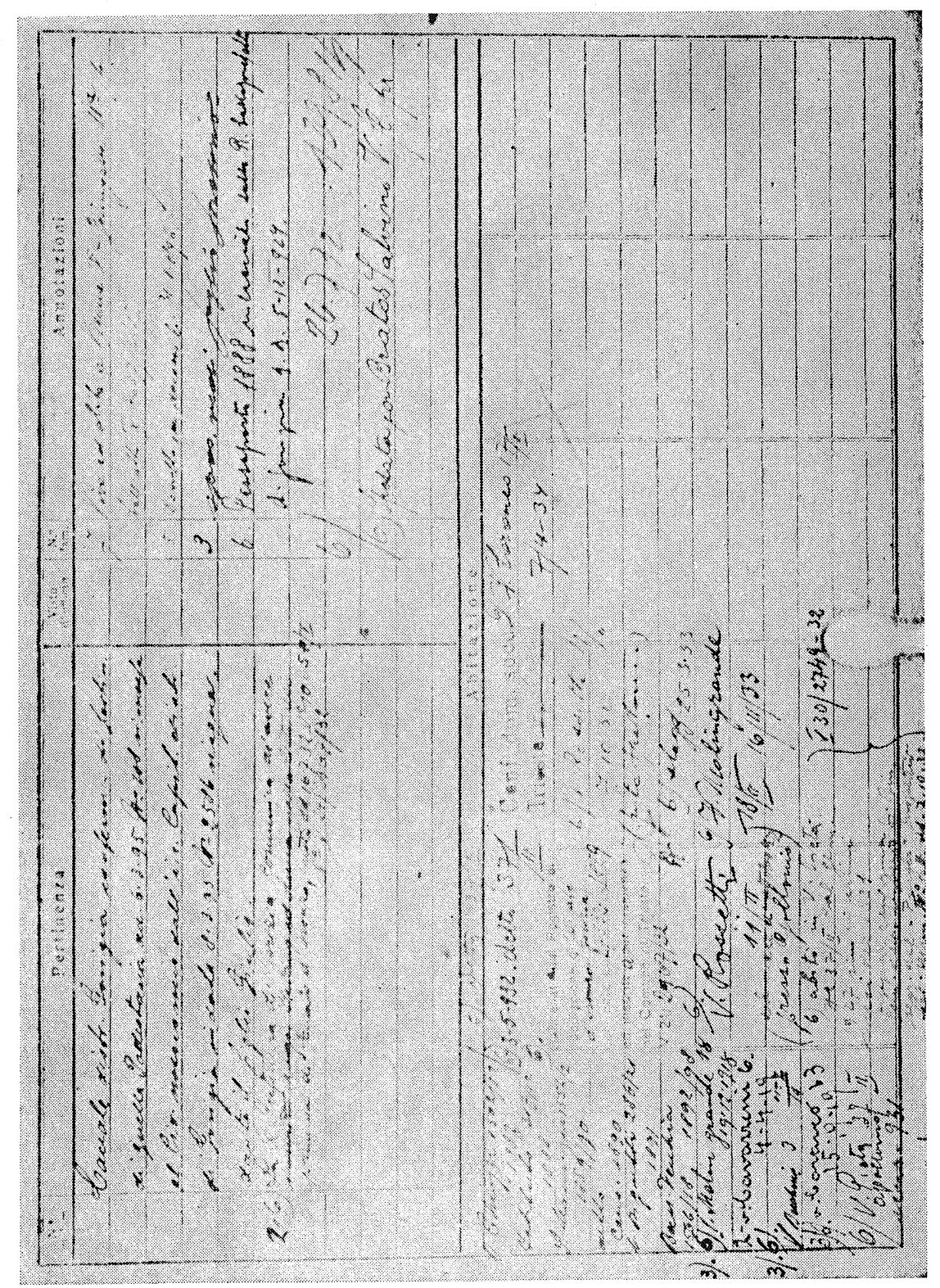

Slika št. 8 